$\begin{array}{ll} & \text { Etnográfica } \\ \text { etnográfica } & \text { Revista do Centro em Rede de Investigação em }\end{array}$

Antropologia

vol. 14 (1) | 2010

Vol. 14 (1)

\title{
Patient information between public space and anthropology: ethnography's contribution to the debate
}

A informação dos doentes entre o espaço público e a antropologia: o contributo da etnografia para o debate

\section{Sylvie Fainzang}

\section{Q OpenEdition}

\section{Journals}

\section{Edição electrónica}

URL: https://journals.openedition.org/etnografica/166

DOI: $10.4000 /$ etnografica. 166

ISSN: 2182-2891

\section{Editora}

Centro em Rede de Investigação em Antropologia

\section{Edição impressa}

Data de publição: 1 fevereiro 2010

Paginação: 97-114

ISSN: 0873-6561

\section{Refêrencia eletrónica}

Sylvie Fainzang, «Patient information between public space and anthropology: ethnography's contribution to the debate», Etnográfica [Online], vol. 14 (1) | 2010, posto online no dia 21 outubro 2011 , consultado o 12 fevereiro 2022. URL: http://journals.openedition.org/etnografica/166 ; DOI: https:// doi.org/10.4000/etnografica.166

\section{(c) (†) 8}

Etnográfica is licensed under a Creative Commons Attribution-NonCommercial 4.0 International License. 


\title{
Patient information between public space and anthropology: ethnography's contribution to the debate
}

\begin{abstract}
Sylvie Fainzang
At some stage of public debate, anthropology must examine important social questions; but in order to properly fulfil its task, it must problematize such questions in ways that differ from those used in the public sphere. In this article we use research carried out on information and lies in the doctor-patient relationship to explore the role that the public debate on patient information played in the development of this research, while emphasizing the distinctive process of anthropological inquiry. We will look at how the research project developed both as an echo of and in disparity with the questions circulating on this matter in the public sphere. We will show that the role of the anthropologist, in order to develop an ethnographic approach, is to take distance from the public debate by transforming the research object through the gradual construction of the problem to be studied. We will also show what ethnography has contributed to the debate and how its observations have reoriented it, approaching it in more sociological and more critical terms.
\end{abstract}

KEYWORDS: doctor-patient relationship, social inequalities, informed consent, cancer announcement, lie, autonomy.

IN THE HUGE CURRENT DEBATE ON THE RELATIONSHIPS BETWEEN sciences and society, in order to examine the links between public space and anthropology, one must - prior to or after research - examine the questions asked by society in relation to those of the research. Yet, however social a question at the root of ethnographic research may be, it does not necessarily correspond to social demand. Whilst the ethnographic approach can be rooted in the existence of a social question (be it explicitly phrased by the media, public institutions, associations or any other means of public expression), for anthropologists, examining a social issue does not necessarily mean expressing 
the question in the terms used by the public sphere. Indeed, the role of anthropologists is to construct their ethnographic approach and thus to stand back from public debate by giving themselves a new object or by changing it. This supposes a critical stance in relation to the categories of one's own discipline, continuously refreshing them by listening to the public sphere, but it also supposes distancing oneself from questions from the public sphere, processing the data and reformulating the problematic.

Above and beyond the formulation of the problematic, through its particular sensitivity to the words used and to the gestures made by the subjects, to their discourses and their practices within a given social context, the ethnographic approach must throw new light on the issue under discussion, a light which also allows the question to be reoriented. It is thus a reciprocal movement between public sphere and anthropology that we will attempt to decode in this article.

We will present the current framework for public debate, within the field of health, on patients' place within the healthcare system, with a view to examining, on the one hand, the extent to which this debate helped develop anthropological research that I recently carried out on information and lies in doctor-patient relationships (Fainzang 2006) and, on the other hand, how ethnography has helped to redefine the debate. Adopting this perspective will allow me to underline the dynamics proper to ethnographic interrogation, i. e. to show how the problematic specific to research was constructed (both as an echo of and in disparity with the questions circulating in the public arena). In return, we will show how this construction and the ethnographic data that it favoured made it possible to reorient the debate. We will thus set out the main results of our research in order to highlight what ethnographic observation yielded and what it contributed to later developments.

\section{THE NATURE OF THE DEBATE}

French society is currently involved in a major debate on patients' place in the healthcare system. Numerous segments of the social sphere are promoting the new role of patients and are making themselves heard in various ways (forums, associations, publications, etc.). Among the strongest points of this debate we find questions as diverse and complex as patient information, informed consent, the practice of more humane medicine and patients' participation in their own treatment. This debate has been largely driven by patients associations, within the field of AIDS in particular.

One concrete example of the enactment of the new role of patients within the social space was the States General of patients with cancer, held in 1999 by initiative of the French National League against Cancer (see Ligue nationale contre le cancer 1999). As in other public demonstrations, this meeting 
affirmed the need to take patients into consideration, to treat them more humanely and to rethink forms of patient-doctor communication and the ways in which illness is announced. Underlying these demands was the idea that patients should be allowed to shift their status from that of object to that of subject, one with access to the information needed to make decisions and to whom healthcare professionals and society should show more humanity. This debate essentially revolved around the questions of competence and ethics (Abiven 1996; Hirsh 1999; Sicard 2000; Reich 2004). Certain sociologists were stakeholders in this debate (Rabeharisoa and Callon 1999), basing their works on the stance that involves asserting loud and clear the role of patients as actors and fighting for their position to be recognized - albeit without one necessarily knowing whether this role is an observed one or one that is being demanded, i.e. whether a patients' "autonomy" is a proven and observed social phenomenon, or whether it is a hobby-horse, one issue among many in the debate surrounding the place of modern-day patients.

In this context, other voices made themselves heard, those of certain healthcare professionals who, at worst expressed their scepticism with regard to patient competence, and at best, their own incapacity to deal with the human aspects of the cure-care process. In the latter case, they put forward both technical reasons - for example, the lack of time, in particular for gradually and gently announcing the diagnosis of a serious illness, or for explaining the medical jargon to the patients - and psychological reasons - especially the difficulty that patients have in accepting and digesting what they are told about their illness (Moley-Massol 2004; Oken 1961; Ong et al. 1995). It is also noteworthy that literature on this question, be it from the medical milieu, from patients associations or sometimes even from the academic sphere - sociologists or philosophers (Fletcher 1979; Bok 1979) - generally defends a given position, either that of doctors or that of patients. Indeed, it has trouble removing itself from the passionate debate surrounding the question of information. The intensity of public debate on this issue gave rise to the introduction of the French law of 4 March 2002, known as the "law on patient rights", which guarantees every individual's right to access to "all information relating to his or her health", marking a victory for patients' claims. It is no coincidence that we sometimes use the expression "public arena" to denote the public sphere. Unlike "sphere" or "space", "arena" has connotations of combat and is thus particularly revealing, the debates in question being of a relatively polemic nature.

This does not mean that anthropology has to take the stance of either supporter or opponent. In order to make the best possible contribution to both public and theoretical debate, researchers must be able to forget their expectations and presuppositions. In other words, they must not jump straight into the arena, but must ensure the conditions that will enable them to understand the parties in conflict. Anthropologists must discover how to look at the issue 
from afar, even if they are later led to state their choices and options (social, political, philosophical). It is only at the end of the analysis that they can choose to enter the fight that is taking place in the public sphere, not as citizens but as researchers.

With regard to this debate, it is important to first of all check the actuality of patient information and to submit the object to the trial of fieldwork. But researchers must also consider the matter from another angle and decentre their attention. In other words, they must problematise the issue in a different way, otherwise they will simply end up confirming or refuting an issue that has been defined by the actors themselves. Such decentring is achieved through ethnographic study and, above all, by constructing the modes of study. It should be noted that the construction of the object, included in the problematisation, is indissociable from the methodology. This is why I felt that it was necessary to conduct a double study of both patients and doctors.

\section{THE STUDY}

The study took place in hospital departments (oncology and internal medicine). It covered 80 patients, 60 with cancer and 20 with other pathologies, including chronic inflammatory or autoimmune diseases. I met the patients at different stages of illness, some being considered as virtually cured and only coming into hospital for check-ups, some receiving treatments (chemotherapy, radiotherapy, surgery) and some under palliative care. They were of different ages (between 30 and 80 years old), of both sexes and from various socioprofessional backgrounds (secretaries, accountants, teachers, medical staff, researcher, maintenance staff, company directors, soldier, shopkeepers, engineers, winegrowers, office staff, sommelier, sales representative, persons on minimum welfare, administrative executives, service personnel, petroleum engineer, artists, artisans, labourers, unemployed).

With the aim of the research being to highlight the logics and mechanisms at the root of information exchange between doctors and patients, from a methodological point of view the investigation consisted in observing medical consultations and then separately meeting the doctors and the patients in order to see how the verbal exchange was constructed and to decode the reasons and mechanisms of their acts and words. I also used open interviews with patients to collect narratives on the illness and therapeutic trajectories, paying attention to the context in which the illness appeared, the different stages of its cure-care process, the questions that the patients asked themselves, the questions they did or did not ask the medical personnel, the answers they were given, the conditions under which they were told the diagnosis, the information they were given or not given, and their reactions. There were also non-directive interviews with 12 doctors in order to learn how they see the 
issue of information and how they perceive patient expectations, with a view to measuring any difference between the hopes that patients declared and the hopes they were perceived to have.

Where possible, doctors and patients were interviewed just after the consultation. Where this was not possible, they were interviewed later on, sometimes several days later. For some of them, these interviews took the form of a sort of "debriefing" during which they explained what they had said, why they had said it, what they had not said and why they had not said it. To achieve this, I met the interviewees both at the hospital (in various environments: consultation rooms, daytime hospitalisations, weekly hospitalisations, meetings of healthcare personnel), and outside the hospital - in particular at patients' homes where they found it easier to talk -, in order to diversify the places where I was interacting with the interviewees, be they patients, doctors, other healthcare personnel or patients' families. This process allowed me not only to gather data on how doctors give patients information, but also on how patients pass on information to doctors, and sometimes on the lies that the former tell the latter.

Access to this particular field was not easy, due to the fact that healthcare professionals seem to feel that nowadays the issue of information in oncology is limited to just the announcement, and in particular to the question of knowing how to "tell" the diagnosis (gently, and whilst respecting the patient's rhythms). Indeed, there is nowadays a widespread belief among healthcare professionals that "there is almost never anything not said regarding the diagnosis", the debate being more about how to announce the diagnosis, certain professionals nevertheless feeling that the announcement cannot be standardized (Lévy-Soussan 2004).

Considering existing legislation, the majority of healthcare professionals thus feel that nowadays patient information is total. In such conditions, doctors feel that the presence of anthropologists wishing to study patient information is only pertinent if the results of the research are likely to answer questions on the best conditions for announcing diagnoses. The healthcare professionals were quick to find room for a researcher who would work with them to determine how, under the best possible psychological conditions, to announce to patients that they have a serious disease. I had to resist this pressure in order to avoid being drawn into this problematic, because in fact the issue goes far beyond the way in which the announcement is made, a question to which the debate tends to reduce it. It covers not just the announcement of the diagnosis and its evolution, but also treatments and their effects, risks and benefits.

Regarding ethnographic tradition, it is important to note that the fact of working on two groups at the same time does not involve working on two objects. Anthropology traditionally tends to construct its object by identifying it with a group that it places at the core of its research. Anthropology's 
focalisation on a group is what usually leads it to only see its object from the point of view of the actors involved. Anthropologists wanting to depart from this grid by creating conditions of distanciation, nevertheless generally base themselves on categories of thought which can be identified with those in the group being studied. Here on the other hand, the object of the research necessarily included two groups, because its aim was to examine what the two groups said to one another. The research was thus based on two distinct orders of thought, possibly antagonistic, respectively produced by patients and doctors, and whose confrontation was all the more complex as one group sometimes echoed the other (after interiorization of the medical discourse), and that both were also marked by a certain heterogeneousness. To achieve this, it was important not to favour one point of view over the other, not to take sides. So it was not a case of doing an ethnography of either doctors or patients, which would have led the researcher to become empathetic with one or the other (in an exclusive manner), but to develop an anthropology of a relationship involving both sides, and in regard to whom the ethnographic approach (with the immersion and observation that this entails), through the dual empathy that was created, became the best tool with which to achieve this decentring. It was a case of maintaining a distance (standard prerequisite in anthropology) not only from the object under study, but also from the presuppositions that any researcher will inevitably have on the subject, as an ordinary citizen. (This is indeed a necessity that is hard to enforce, because as individuals, researchers are also part of the debate.) In this respect, to the need for "distancing" (which involves not adopting the same way of thinking as the group under study) must be added the need for "decentring" (which requires silencing or modifying one's own reference system and not becoming involved in the heart of the debate). In addition to the distancing from the object, there is thus also distancing from the social debate in which the object is included, with researchers "shifting" and attempting to alternately put themselves in the place of the various protagonists of the relationship in question.

This requirement for decentring is even greater given that the doctor-patient relationship is socially defined as potentially being one of conflict, not only due to the changing nature of patients' status in modern society in relation to doctors, but also due to the related issues at stake revolving around the question of rights and powers (that the satellite notions of "autonomy", "consent" and "negotiation" convey).

At a more strictly problematical level, following in the footsteps of the public debate on patient information (mainly revolving - especially as far as the stances of patient associations are concerned - around the best way of telling patients the truth about their diagnoses) was to risk either becoming mere spokespersons for said associations (which is not the researcher's role) or to subject the study to a biomedical problematic by reducing the debate to 
merely the ethical or therapeutic stances of the healthcare personnel. It was thus first of all a question of re-examining that which was considered as "obvious" by gathering ethnographic material out in the field, and also of accepting that we had to come up with an analysis of lies (at the risk of using a term that the medical profession deems to be irreverent). My decision was thus to also break away from the stance adopted by most works carried out on the question of truth in medicine. Unlike works done within the framework of these debates, most of which are works that either take the form of justifications of what is referred to as "therapeutic privilege" or else pleas for patient participation, it became vital to change the way in which these issues are generally approached.

Because the question of truth and lies is often put forward in ethical terms, many authors choose it as their subject, in order to defend a particular position. They examine the ethical questions that are raised, in particular, by the way in which a prognosis is formulated or by the fact that patients are asked to give consent without having all the information they need to make a decision. However, this is not the purpose here. Here we are looking at the issue from the angle of the social sciences. In other words, we are analysing a situation without inferring any normative position.

Some authors believe that the problem goes beyond that of telling or not telling a truth, given the context of the uncertainty of knowledge, especially in the field of cancer. But whilst the reality of the uncertainty is indeed both an obstacle to truth and, above all, an argument used by doctors to conceal the truth from patients, it is far from exhausting the issue of information. In this respect, the question of truth must be asked in both a comprehensive and extensive manner. The notion of truth, which Fletcher (1979) separates into logical truth (accuracy) and moral truth (veracity), is clearly linked to that of lies. Fletcher states that accuracy is the relationship between the verbal expression and the issue to which that expression applies, whereas veracity is the relationship between the expression given to a thought and the thought itself. Accuracy is therefore the truth as far as we know it; veracity is the truth which corresponds to that which we believe to be true. It is the latter sense that interests us here - that which the liar thinks to be true. Thus the aim of this study was not to give yet another opinion on the issue of whether or not it is preferable to tell a patient the truth, but to examine the arguments used by the protagonists in the doctor-patient relationship to explain their behaviour, and, above all, to find out what their stances and practices conceal and imply. Simmel (1964) says that the characteristic of the lie is not that the person being lied to has a false idea of the reality - for this is something that the lie has in common with error - but that he/she is deceived with regard to the liar's opinion.

Our approach thus supposes a certain number of epistemological conditions. Firstly, as we have seen, it supposes that from an emic point of view we 
start with that which the liar believes to be true. This then supposes that we accept the purposely iconoclastic nature of the term "lie" as applied to the medical profession. Is it not the role of the social sciences, where so required, to question icons? Furthermore, examining lies as a bilateral practice made it possible to shift focus and to look at the therapeutic relationship as a social relationship.

\section{ETHNOGRAPHIC OBSERVATIONS AND ANALYSIS}

Although convinced that patients are told everything, many doctors nevertheless use all kinds of strategies to avoid stating matters clearly. When observing consultations, I saw various techniques used to reduce the shock that might be incurred when a diagnosis or the results of tests are announced. The most frequent strategy is the tendency to minimize the problem or to take the drama out of the situation. For example, one doctor tells the patient about his "tiny little nodule on the lung" whereas the written examination results mention a "huge pulmonary mass". When doctors feel that the announcement of the treatment is likely to worry the patient more than the diagnosis itself, it is sometimes the treatment that is euphemized. After receiving the results of a biopsy, one oncologist says to her patient: "It's a cancer, we'll start with a little chemo." Still others turn to the patient's family, despite the law on medical secrecy, leaving the family with the responsibility of deciding whether or not to inform the patient.

Regarding treatments and their possible effects, I also observed forms of withholding information through the attitude of certain doctors which consists in discouraging patients from reading the pharmaceutical instructions (Fainzang 2001) with the objective of encouraging them to take the prescribed medicines. They tend not only to keep quiet about unpleasant side effects so that such information does not discourage patients from taking the medicines and to ensure that they will be compliant, but sometimes even deny the information contained in the instructions in order for the patients to submit to the prescription.

In addition, despite the fact that doctors insist that nowadays patients are fully informed of everything relating to their state of health and treatment, the study shows that paradoxically, a certain number of doctors create conditions for the provision of this information, each developing his/her own doctrine on the question.

Some doctors thus inform patients only if the patients so wish. Basing themselves on the widely popularized works of psychologists (for example Ruszniewski 1995; Joseph-Jeanneney et al. 2002), doctors explain the lack of questions asked by patients by the fact that "they don't want to know" or by a "denial" of the illness. Yet the study reveals that this denial is attributed to 
patients who are in fact trying to obtain information on their illness by any means available (from nursing staff, from their attending physician, from other patients, or even from the media and from the Internet) - ready to interpret or even over-interpret any gesture to gain information on their case ${ }^{1}$ - but who do not always dare to ask the doctor (especially if he/she is a professor or a head of department) for reasons which are mainly due to the position of authority that the latter continues to hold in French society. To systematically explain the lack of questions from patients in terms of denial and of refusing to accept the truth is to ignore the sociological dimension of the verbal exchange between doctor and patient. Indeed, this analysis in terms of denial, widespread among health professionals, is taken up by most of the nursing staff who on this point are the doctors' best ambassadors. In the name of patient protection, healthcare professionals now recommend a new right for patients - the right not to know.

I am not challenging this type of analysis, but I am suggesting that the issue of information cannot be reduced to the psychological perspective, and I consequently put forward another analysis which is more sensitive to the social context of information. Many doctors are alarmed that patients say that no-one explains anything to them, whereas they "have explained everything to them!" This leads healthcare professionals to conclude that "patients don't want to hear" bad news. On this point it is interesting to note that the information provided during consultations sometimes bears no relation whatsoever to the questions that patients ask, said questions not being "heard" by the doctors. Indeed, there are numerous consultations where patients ask a question or mention a symptom they are worrying about, without the doctor answering or even paying any attention to it, or where the doctor gives an answer that is not relevant to the question. One patient (retired natural sciences teacher) to whom the oncologist has just announced the persistence of the nodules and the need to restart chemotherapy, says: "After the coloscopy, Dr. M said that the nerve endings in the intestines were not working properly!?" The doctor replies: "There are several possibilities: either you can be given a drip at home once a week from a nurse, or you come into hospital during the day. I suggest you come into the hospital." Here the patient asks a question on the consequences of the coloscopy, and the doctor replies with a choice of where to have the treatment. (The patient does not repeat the question, even though it is worrying him. Indeed, this was the first thing he mentioned when I spoke to him later.)

Other doctors choose to limit information to that which is certain, and only give it if it relates to the diagnosis, drawing a clear line between diagnosis and

I For example, the gesture of the doctor who puts his/her hand on the patient's shoulder at the end of the consultation whilst saying goodbye, can be taken by the patient to mean that he/she arouses compassion because his/her case is serious. 
prognosis due to the uncertainty which is so strongly linked to the latter. Yet even in this case, the diagnosis is not always revealed. Indeed, whilst the presence of cancer is no longer hidden, another fact that is hidden by many doctors is metastasis. This word is often not pronounced, as it has taken on the feared image which used to be associated with the word "cancer". If doctors are now more ready to tell patients that they have cancer, this is because it is nowadays considered to be more of a chronic illness than a fatal illness. If they find it far harder to reveal the presence of metastases in a patient's body, it is because these have taken over the status that used to be held by cancer in general. The reason for hiding this fact is that in such cases the diagnosis includes a prognosis. Telling a patient: "your cancer has metastasised" is to tell him/her both the nature of the problem and its possible outcome, given that the diagnosis itself may be the sign of an unfavourable evolution. Here we see what I will call the "prognostic dimension of the diagnosis". Nowadays we are thus seeing a shift in the dissimulation, in what goes unsaid. The taboo is simply moved, applied to a new object, at another stage of the illness. From silence about the disease we have moved to silence about its complications or worsening, i.e. to a diagnosis which, in the mind of the actors, contains a prognosis.

Other doctors only give patients information if they are able to intellectually understand it, or if they can psychologically cope with it. It is consequently not uncommon for patients not to be informed, on the basis that it is not beneficial, not in their interest and that in their particular cases they should not be told everything.

On this point, anthropologists cannot fail to wonder how doctors decide what is in a patient's interest and on what basis they determine what can be said and to whom. Ethnographic observation of real practices allows us to throw light on the social mechanisms, often unconscious, according to which doctors build their behaviours relating to information. Indeed, it can be seen that information is often given in preference to the higher social categories, a social grade that makes doctors think that not only do patients have a greater aptitude to understand the information, but also a greater capacity to cope with it, this being based on the distinction and assurance that the patients seem to have and flaunt. There are numerous examples which demonstrate that doctors are more ready to discuss diagnoses, types of treatment and their effects with patients who come from a known or supposed upper social milieu or who have the supposed cultural level that goes with it. To one patient suffering from rheumatoid scleroderma, her doctor explains the risks of treatment in detail: "Scleroderma can attack any organ (lung, heart, digestive tube), so we need to prescribe immunodepressors (cortisone), but not too much, because if the immune system is lowered too far, that can lead to infections!" Then the doctor told me later on: "I didn't hide anything from her, she had a sufficient cultural level." Another doctor, speaking on the telephone with an oncologist 
colleague to whom he has referred a patient, and being asked if she (the patient) can be told the truth about her diagnosis, replied: "You can go ahead, she's a teacher." Yet another doctor, asked after a consultation why he had given his patient such a detailed diagnosis, one that was not however very positive, told me: "I could see that he had a high-level intellectual profile."

This conviction sometimes leads doctors to give patients information that they have not requested and thus to presuppose their desire to know and their capacity to cope. A company director who had done his studies in a top business school was given a very detailed explanation of the antibody treatment that he was being offered. Although he had not asked his doctor any questions, the doctor nevertheless gave him thorough information, based on an impression - that of the patient's ability to understand, in line with his social presence.

Information is thus provided in different ways, depending on the patient's sociocultural category. One remarkable point on this matter is that doctors base their assessment either on their detailed knowledge of the patient's file and the information contained therein (civil status, profession, etc.), or - when they do not have the time to read the file and when they do not know the patient or the information is not provided in the file - on the feeling that the patient gives with regard to social category. Doctors' behaviours thus depend not only on patients' psychological dispositions, as they claim, but also very much on their social characteristics, the latter being used to assess the former. To the sadly famous social inequalities of access to health care, we can therefore add the social inequality of access to information that this mechanism helps to preserve.

The mechanisms governing the withholding of information are also at the root of outright lying. But lies can take the form of manipulation of the truth, through a play on words: Mrs. C has an incurable cancer of the liver and her life expectancy is considerably reduced. The doctor talks to her about a "therapeutic break" as a way of saying that in reality the treatment has failed and that it must be stopped: "We no longer have any hope of curing her. In fact, we are giving up, but I prefer to tell her that we are taking a break."

It should be noted that in the same way that doctors tend to lie to patients of lower social status, in a symmetrical manner patients of this status also tend to lie more frequently. Indeed, lies and the non-provision of information which exist within therapeutic relationships are not the prerogative of doctors. They can also be found among patients, who sometimes hide certain symptoms or behaviours at the risk of preventing healthcare personnel from doing their job efficiently and of being prejudicial to a good cure-care process. A new symptom may be dissimulated through the desire to refuse to allow the problem to exist (being in this respect similar to denial) and to prevent the doctor from making a hypothesis of worsening health. It is what we might call the performative nature of lying in as much as it aims to prevent a negative diagnosis from being 
made. This is the case for example of Mrs. N, who pretends that she is not in pain when in fact she is suffering enormously after an operation for cancer. But telling the truth about her pain is to make the problem exist and to render what she believes to be a treatment failure real; a failure that, by lying, she is attempting to remove.

On the other hand, the dissimulation of behaviour (therapeutic or otherwise, such as following alternative treatments, self-medication, choosing to take or not to take contraception, etc.) is symptomatic of patients' fear of telling doctors about behaviour which the doctors might criticize. It can also result from the desire not to allow doctors to interfere with one's life. One patient (service personnel) suffering from serious rheumatoid polyarthritis, does two hours of sport per day, including cardio-training. But she does not tell her doctor for fear of being reprimanded. She says: "I don't want to tell the doctor, I'm too scared he'll stop me from doing it! Maybe it's not good for me!" This fear relates to the relationship that the patient has with the doctor as a figure of authority.

The study also revealed the existence of numerous "misunderstandings" between doctors and patients, which I used as a basis for addressing, in a critical manner, the question of doctor-patient communication, of the latter's decision-making power and of the nature of the medical relationship. These misunderstandings go far beyond the issue of not understanding medical jargon. There are of course misunderstandings resulting from the ambiguity or polysemy of certain terms. For example, one major difficulty concerns the notion of "clinical trial", a term which does not always let patients know whether they are being offered the opportunity to take part in a research protocol or whether they are being treated by a new clinical protocol. This confusion leads certain patients to be surprised that their doctors do not ask them to sign an informed consent form when they propose a new treatment, whereas other patients, who are asked to sign an informed consent form in order to take part in a clinical trial, are surprised that they were not asked to sign for the previous one. In reality, they often sign this form without understanding the meaning of the authorisation that is being requested. This situation makes one wonder if it would not be more accurate to use the expression "resigned consent" rather than "informed consent".

But there are also certain "misunderstandings" due to the fact that patients' questions are not heard or understood. Mrs. A arrives for her consultation and worriedly tells her oncologist: "The gynaecologist found a small cyst on an ovary!", to which the doctor replies: "Both breasts are fine. We'll do another scan in two months. Do you have any questions?" In fact she has just asked an implicit question, by worriedly commenting on the presence of the cyst, but he did not reply. She does not repeat her comment and leaves the consultation without receiving an answer. 
Another source of misunderstanding is incomplete information, for example concerning age. When one says to a patient, as so many doctors do, "given your age", one is not, in the strict sense of the expression, saying whether the patient's age is high or low; and some patients can take this as a reassuring comment whilst others see it as a problem. One doctor telephones a colleague in the clinical trial department. In front of the patient and referring to her, he says: "she is very young. There is a reserved prognosis, with ganglions; I'd like to put her in an intensive protocol with dense dosage." After the consultation the patient told me: "There's a reserved prognosis because I'm young, that's what the doctor told his colleague on the phone." What the doctor told me was: "I want to give her every chance because she is young." On the basis of this sentence containing three statements, the patient links the first and second statements, whilst the doctor links the first and the third.

One of the problems of patient information is also due to the difference between the respective concerns of doctors and patients. For example, during a consultation where a doctor tells a patient that he is going to give her additional chemotherapy, the patient asks a series of questions about the risk of her hair falling out again under the new treatment, about whether or not she will be allowed to dye it when it grows again, etc. Her numerous questions annoy the doctor because he thinks they are futile compared to what is at stake for her health. In fact, this patient is even more worried about the possible effect of the treatment and of becoming ugly because her husband is having an affair and she sees the risk of bodily degradation as a risk of an acceleration in the deterioration of her marriage. In this case the requested information relates not to her health but to her marriage. This shows the difference between the respective concerns of doctors and patients, exclusively health-based for the former, sometimes mainly social for the latter, a difference which can also lead to misunderstandings. When patients ask for information, health issues are not necessarily given greater importance than social or relational matters.

Communication can also be hindered by questions left unanswered or by a doctor's assessment of a patient's request for information, in as much as the request tends to be "pathologised". A patient asks her oncologist to explain the meaning of the word "differentiated" which she has heard used to describe the tumour of her husband, who is being treated in the same hospital. Later on she tells him that she is perplexed that two doctors in the ward say different things about her husband's cancer, and she asks her oncologist for his opinion - a question which goes unanswered. (This point refers to the difficulties caused by the contradiction that sometimes exists between the comments made by different members of the healthcare team.) At the end of the consultation, the oncologist asks her: "Would you like an anxiolytic?" This patient's worry, legitimately caused by unclear or contradictory comments, is thus treated as 
a pathology, and she is prescribed psychotropics. This illustrates the social treatment of patients' requests for information, in this case consisting in a pathologisation.

\section{ETHNOGRAPHY'S CONTRIBUTION:}

BETWEEN PUBLIC SPHERE AND ACADEMIC SPHERE

After the research is done, we cannot of course avoid the question of what ethnography contributes to the public sphere, through the decentring achieved during the study: in contrast with the contours of the social debate outlined above, focusing in particular on the validity (or not) of full patient information, the ethnographic approach highlighted, as we have seen, the mechanisms of this information and the social inequalities involved. Ethnography's contribution to the public debate leads to a change in perspective. It is no longer just a case of looking at what medical practice (by informing or not informing the patient) induces at the therapeutic level (for the patient's benefit or prejudice), but also of what it induces at the social level. The deconstruction of the question and the decentring of the researcher allows him to put the question back into the public sphere in a new form. This change is made possible both by taking the public debate into consideration and through the reproblematisation that the anthropological approach achieves, in the course of its observations.

First, as we have seen, the question of information goes beyond the issue of announcement in which the anthropologist risked becoming trapped. Furthermore, the problems of communication between doctors and patients do not result solely from the use of different linguistic codes (with, in particular, the classic reference to the existence of a medical jargon that patients do not understand), nor solely from the psychological difficulties generated by the announcement of a serious illness. Indeed, we have seen that this information was linked just as much, if not more, to social rather than psychological criteria. The practices of information and lying are part of a mechanism of social reproduction, by virtue of which doctors, wishing to fall in with the supposed capacity of the patients to receive the information, only give it to those who usually own it in society. Thus inequalities of access to medical information do not result just from the insufficiency of the tools that society gives certain patients to allow them to understand it, but also from the fact that, a priori, information is withheld from patients belonging to certain social milieus.

As we have also seen, ethnographic observation allows us to reveal the persistent existence of a taboo with regard to revealing the truth about metastases. Anthropology enables us to call into question the consensus which currently exists in the medical world regarding "full" patient information, thus fulfilling one part of its task - that of re-examining that which seems "obvious". 
Furthermore, however rooted in social debate it may be, ethnography allows us to re-examine academic works carried out on speech and lies. These works have shown, quite correctly, that the alliance between power and speech is a general phenomenon of social functioning. In some societies, social law merges in particular with a law of silence, in accordance with which the strategy of power is to remain silent (Augé 1974). As specific speech, a lie must be examined inside a relationship of power. It too is the exercise of the power and withholding of knowledge, because doctors jealously preserve knowledge from those dependent on them. Reflecting on the withholding of knowledge, Roqueplo (1974) showed that it was a case of preserving one's own position in the social hierarchy and that to share knowledge was to share power. Like the withholding of knowledge, the status of lying as a technique to restrict the social distribution of knowledge is a sociological mechanism that anthropology has clearly highlighted by showing that it is intertwined with power and with the control of society (Gilsenan 1976). This logic is at work in very diverse societies: for example, among the Bissa people in Burkina-Faso, the links between lies and truth on the one hand and power on the other hand are expressed in the rules governing the disclosure of divinatory diagnosis; divinatory consultation and the disclosure of its results are thus governed by a strict codification which follows the rule of access to knowledge, from which knowledge relating to diagnosis does not escape: a young man, even if adult, must tell the truth to his elders, but he has the right to "lie" to women (Fainzang 1986). Lying is indeed part of political life, in as much as it is a direct weapon or strategy at the service of a power. ${ }^{2}$

Yet despite what we learn from classic anthropological analyses of lies, the ethnography of the doctor-patient relationship shows that it is not a weapon available only to those in power. Lying is also a weapon used by the weak, as it is precisely because they fear doctors as figures of authority that patients use lies. But neither is it just "the weapon of the weak", to use the expression coined by Scott (1985, quoted by Scheper-Hughes 2005) and by Scheper-Hughes (2005). Because those who have no power tend to use forms of resistance that include dissimulation and lying, we cannot conclude that lying illustrates the sole medical power that doctors wield at patients' expense. The situation is more complex than that. In reality, theoretical reflection on lies between doctors and patients has to be performed in the context of their new social roles. Yet the complexity of the question is linked to the existence of conflicting roles. The new figure of the doctor is the result of the combination of social training in the use of the "therapeutic privilege" allowing doctors

2 On this point one might refer to the work by Rabaté (2005), a philosophical meditation on lying and in particular on lying in politics, taking up certain of Koyré's ideas (1996 [1944]) on the political function of the modern lie. 
not to divulge information (continuation of the paternalist relationship), and the legal obligation to inform patients. The new figure of the patients results from both their obligation to subject themselves to medical authority and their newfound right to assert their autonomy. Whilst the ethnographic study has allowed us to rethink the doctor-patient relationship, it has also enabled us to rethink lying as a social practice, its meaning and function here residing in the tension between the choice of conforming with or resisting the social roles allocated or defined by society. The use of lying, within this relationship, is a function of the evolution of these roles. It is both the enacting of and the resistance to the new social roles - possibly contradictory - that have been assigned to them.

\section{CONCLUSION}

Numerous social science researchers tend to either espouse or repudiate public debates. Some embrace the ideas of social combat, going so far as to formulate their research in the exact line of the questions raised by the media or by the actors present in the arenas. Others look at public debate with contempt, and consider that it should in no way interfere with fundamental research, relegating any works which might serve its cause to the level of research-action. Another avenue is that which consists in stepping away from the presupposed aspects of public debate, in order to affirm a specific and original disciplinary approach through which to re-examine social issues in one's own eyes - perhaps the most beneficial way to make them progress.

In the present case, the heuristic dimension of the approach is closely linked to its fruitfulness for social stakes, because by constructing a new stance, borrowed from the axiomatic foundations of the discipline, it rebuilds the object, paving the way for new observations on the fringe of those made by other disciplines such as medicine and psychology. Indeed, as a counterpoint to the psychological perspective from which existing literature looks at the issue of patient information, considering that the truth should be told to those who are psychologically capable of hearing it, it was important to "de-psychologise" the approach to this phenomenon and to examine its social mechanisms. By breaking away from the standard explanations of a psychological nature, so ever-present in the public sphere, ethnographic research made it possible to highlight truly anthropological or sociological mechanisms and thus give a new direction to the debate. In this case, the study made it possible to demonstrate the sociological mechanisms underlying patient information.

Anthropology can examine a social question, but it has to ask the question in its own terms, with its own tools, its own particular epistemological stance, and it is this decentring that allows it to produce new results that can be returned to the public sphere and which can enrich or help to redirect the 
debate. Ethnology and public sphere thus dance a pas de deux, in an enterprise of jointly constructing knowledge, albeit on the condition that the former is able to free itself from the forms given to the questions that the latter is asking. The effectiveness of its work and of its role in society depends on it. But so does its autonomy, which is its prerequisite. In this sense, the condition of researchers' contribution is sometimes to move outside the framework of the problem inside which others want to enclose them.

\section{REFERENCES}

ABIVEN, M., 1996, "Mentir pour bien faire? Ou le mensonge en médecine", Études Psychothérapiques, 13: 39-50.

AUGÉ, M. (ed.), 1974, La construction du monde: Religions, représentations, idéologies. Paris, Maspéro.

BOK, S., 1979, Lying: Moral Choice in Public and Private Life. New York, Vintage.

FAINZANG, S., 1986, L'intérieur des choses: Maladie, divination et reproduction sociale chez les Bisa du Burkina. Paris, L'Harmattan.

—, 2001, Médicaments et sociétés: Le patient, le médecin et l'ordonnance, Paris, Presses Universitaires de France.

—, 2006, La relation médecins-malades: Information et mensonge. Paris, Presses Universitaires de France.

FLETCHER, J., 1979, Morals and Medicine: The Moral Problems of the Patient's Right to Know the Truth. New Jersey, Princeton University Press.

GILSENAN, M., 1976, "Lying, honor, and contradiction", in B. Kapferer (ed.), Essays in Social Anthropology: Vol. 1, Transaction and Meaning: Directions in the Anthropology of Exchange and Symbolic Behavior. Philadelphia, Institute for the Study of Human Issues, 191-219.

HIRSH, E., 1999, La relation médecin/malade face aux exigences de l'information. Paris, AP-HP/Doin.

JOSEPH-JEANNENEY, et al., 2002, Autour du malade: La famille, le médecin et le psychologue. Paris, Odile Jacob.

KOYRÉ, A., 1996 [1944], Réflexions sur le mensonge. Paris, Éditions Allia.

LÉVY-SOUSSAN, Michèle, 2004, "Subjectivité du malade et normes médicales", paper presented to the "Séminaire du SIRS: Représentations de santé et construction des normes" (available at <http://www.u707.jussieu.fr/sirs/Rencontre\%204\%20Novembre\%202004. $\operatorname{doc}>$ ).

LIGUE NATIONALE CONTRE LE CANCER, 1999, Les malades prennent la parole: Le livre blanc des $1^{\text {ers }}$ États Généraux des Malades du Cancer. Paris, Ramsay.

MOLEY-MASSOL, I., 2004, L'annonce de la maladie: Une parole qui engage. Paris, DaTebe Éditions.

OKEN, D., 1961, "What to tell cancer patients: a study of medical attitudes", The Journal of the American Medical Association, 175: 1120-1 128. 
ONG, L.M.L., et al., 1995, "Doctor/patient communication: a review of the literature", Social Science and Medicine, 40 (7): 903-918.

RABATÉ, J.-M., 2005, Tout dire ou ne rien dire: Logiques du mensonge. Paris, Stock.

RABEHARISOA, V., and M. CALLON, 1999, Le pouvoir des malades: L'Association Française contre les Myopathies et la recherche. Paris, Presses de l'École des Mines.

REICH, M., 2004, "L'information diagnostique et pronostique à l'épreuve des avancées thérapeutiques en cancérologie: réflexions éthiques", Revue Francophone de Psycho-Oncologie, 3 (4): 188-196.

ROQUEPLO, P., 1974, Le partage du savoir: Science, culture, vulgarisation. Paris, Seuil.

RUSZNIEWSKI, M., 1995, Face à la Maladie Grave: Patients, Familles, Soignants. Paris, Privat/Dunot.

SCHEPER-HUGHES, Nancy, 2005, "Disease or deception: Munchausen by proxy as a weapon of the weak", in E. van Dongen and S. Fainzang (eds.), Lying and Illness: Power and Performance. Amsterdam, Het Spinhuis, 113-138.

SCOTT, J., 1985, Weapons of the Weak. New Haven, Yale University.

SICARD, D., 2000, "Le médecin et ses malades: le malade et ses médecins", in Yves Michaud (ed.), Qu'est-ce que l'humain? Vol. 2, Université de tous les savoirs. Paris, Odile Jacob.

SIMMEL, G., 1964, "The secret and the secret society", in G. Simmel, The Sociology of Georg Simmel, Glencoe, IL, and London, The Free Press.

A informação dos doentes entre o espaço público e a antropologia: o contributo da etnografia para o debate - Sylvie Fainzang - CERMES-INSERM, França • sylvie.fainzang@orange.fr

A um dado momento do debate público a antropologia tem de analisar questões sociais importantes, mas, para que possa levar a cabo a sua tarefa, terá de problematizar essas questões de maneira diferente da que é seguida no domínio público. Neste artigo partimos de uma pesquisa sobre a informação e a mentira na relação entre médico e paciente para explorar o papel desempenhado pelo debate público sobre a informação dos doentes no desenvolvimento dessa pesquisa, embora enfatizando o processo característico da investigação antropológica. Veremos como esse projecto de investigação se desenvolveu fazendo eco, mas distinguindo-se, simultaneamente, das questões que circulavam a esse respeito na esfera pública. Mostraremos que o papel do antropólogo, quando desenvolve uma abordagem etnográfica, deve ser o de se distanciar do debate público, transformando o objecto de estudo através da construção gradual do problema a ser estudado. Mostraremos também como a etnografia contribuiu para o debate e como as observações da primeira deram uma nova orientação ao segundo, ao formulá-lo em termos mais sociológicos e mais críticos.

PALAVRAS-CHAVE: relações médico-paciente, desigualdade social, consentimento informado, anúncio do cancro, mentira, autonomia. 